\title{
Sistem Informasi Penentuan Kelas Santri Baru Berbasis Web pada Pondok Pesantren Tarbiyatul Khoirot
}

\author{
Fatimatul Ulya $^{1 *}$, Arief Hidayat ${ }^{2}$ \\ 1,2 Jurusan Teknik Informatika, Fakultas Teknik, Universitas Wahid Hasyim \\ Jl. Menoreh Tengah X/22 Sampangan Semarang 50236 \\ *Email : ulyafatimatul33@gmail.com
}

\begin{abstract}
Abstrak
Madrasah diniyah merupakan lembaga pendidikan yang memberikan pendidikan dan pengajaran secara klasikal yang bertujuan untuk memberi tambahan pengetahuan agama islam. Sebelum masuk pada kelas madrasah diniyah terdapat ujian menentukan kelas atau seleksi. Ujian seleksi sering dikenal dengan istilah "ujian saringan" atau "ujian masuk". Namun, ujian seleksi di Pondok Pesantren Tarbiyatul Khoirot ini diterapkan bukan untuk menerima atau menolak santri yang akan mendaftar di pondok melainkan untuk mengukur sejauh mana kemampuan dan pemahaman seorang santri, yang hasilnya digunakan untuk menentukan kelas Madrasah Diniyah sesuai tingkatan kemampuan dan pemahaman santri baru tersebut. Oleh karena itu, mengingat waktu pelaksaan ujian yang tidak menentu serta kurang efisien baik dari segi kualitas, kepraktisan, kecepatan dan kemudahan maka dibuatlah "Sistem Informasi Penentuan Kelas Santri Baru Berbasis Web Pada Pondok Pesantren Tarbiyatul Khoirot”. Dalam pembuatan sistem informasi ini penulis menggunakan metode waterfall sebagai yang umum dikenal, prosesnya pun mengalir secara sistematis dari tahap satu ke tahap lainnya dalam mode ke bawah. Hasil dari penelitian ini yaitu suatu sistem ujian sebagai penentuan kelas yang ditujukan untuk santri baru yang soalnya berupa huruf pegon atau arab.
\end{abstract}

Kata kunci: Penentuan Kelas, Pondok Pesantren, Santri, Sistem Informasi, Waterfall

\section{PENDAHULUAN}

Tuntutan global agar selalu dan senantiasa menyesuaikan penggunaan teknologi informasi dan komunikasi menjadikan pondok pesantren memerlukan inovasi dan kreativitas agar dimudahkan dalam melaksanakan tugas dan kepentingannya dari mulai mendaftar, seleksi penerimaan santri baru, pelayanan administrasi, pembayaran syahriyah, dan lain sebagainya yang masih dilakukan secara manual.

Pada penerimaan santri baru Pondok Pesantren Tarbiyatul Khoirot terdapat ujian seleksi setelah di terima menjadi santri, yang mana ujian tersebut dilakukan untuk mengukur sejauh mana kemampuan dan pemahaman seorang santri, hasilnya digunakan untuk menentukan kelas Madrasah Diniyah sesuai tingkatan kemampuan dan pemahaman santri baru tersebut. Disamping itu waktu pelaksaan ujian yang tidak menentu serta kurang efisien baik dari segi kualitas, kepraktisan, kecepatan dan kemudahan. Berdasarkan hal tersebut diperlukan suatu inovasi agar dapat membantu dalam menyeleksi menentukan kelas bagi santri baru dengan membuat sistem informasi penentuan kelas santri baru berbasis web pada Pondok Pesantren Tarbiyatul Khoirot.

\section{TINJAUAN PUSTAKA}

\subsection{Landasan Pustaka}

Penelitian serupa tentang ujian online yang dilakukan oleh (Julianti dan Silalahi, 2015) yang berjudul "Perancangan Aplikasi Ujian Online Berbasis Web Studi Kasus di STMIK Bina Srana Global" bertujuan memudahkan sistem ujian yang masih manual dan banyak kelemahan. Karena tidak adanya backup data yang jelas dan pasti sehingga jika dibutuhkan data yang mendadak dan sangat sulit untuk langsung dilaporkan. Metode yang digunakan menggunakan pemodelan analisis terstruktur, yang terdiri dari Data Flow Diagram (DFD), kamus data, dan spesifikasi proses. Hasil penelitian tersebut yaitu sistem ujian online berbasis web ini membuat pekerjaan dalam mengadakan ujian UTS/UAS memberi penilaian dan pelaporan nilai bisa lebih mudah dan cepat dari segi waktu dan biaya. Untuk menjaga keamanan data dan 
keikutsertaan dari pihak yang dikenal maka perlu digunakan password untuk bisa mengikuti ujian dari sistem ini.

Penelitian (Sudaryati, 2016) berjudul "Pengembangan Online Test System Untuk Siswa Sekolah Menengah Atas" mempunyai tujuan mengembangkan sistem ujian berbantuan / berbasis komputer atau computer based test system sebagai upaya menghadapi ujian berbantuan / berbasis komputer. Model pengembangan penelitian ini Linier Sequential di mana ada tahap analysis, requirement specification, design, implementation, testing dan integration, operation and maintenance. Hasil penelitian tersebut pengembangan tes berbasis komputer (computerized based test) atau online test system menghasilkan bentuk aplikasi ujian nasional menggunakan komputer. Aplikasi tersebut merupakan aplikasi yang dirancang guna mempersiapkan siswa SMA untuk menghadapi ujian nasional menggunakan komputer. System offline service yang dikembangkan memudahkan dalam perawatan dan pengoperasian aplikasi, sehingga guru/tim tryout ujian nasional di sekolah-sekolah dapat menggunakan aplikasi dengan mudah.

Berdasarkan kedua penelitian diatas, yang membedakan antara penelitian penelitian yang serupa ini adalah kedua penelitian tersebut merupakan ujian atau tes yang berbasis online pada sekolah formal seperti tingkat Sekolah Menengah Atas dan Perguruan Tinggi yang mana ujian tersebut berupa ujian UTS/UAS dan ujian try out. Bahasa yang digunakan pada penelitian tersebut adalah Bahasa Indonesia dan hasil akhirnya hanya berupa nilai serta keterangan lulus atau tidak lulus. Sedangkan sistem informasi penentuan kelas yang penulis buat ini pertanyaannya menggunakan tulisan Arabic atau pegon dan terdapat pengacakan soal (random), serta hasil akhir setelah mengerjakannya pula tidak hanya berupa nilai, namun juga terdapat keterangan kelas yang diperoleh sesuai nilai ujian.

\subsection{Landasan Teori}

\subsubsection{Ujian}

Ujian adalah salah satu alat ukur kebersihan kegiatan belajar mengajar, meskipun demikian hail ujian bukan satu-satunya alat ukur keberhasilan guru/instruktur/trainer dan pengajar lainnya (Pamungkas, 2015).

\subsubsection{Santri}

Kata santri dijabarkan huruf demi huruf. Santri berasal dari tiga huruf arab. Pertama 'sin' yang mengandung makna 'satrul aurat'. Kedua 'nun' di dalamnya terkandung makna 'naibul ulama'. Ketiga 'ta' dimaknai 'tarikul maasyi'. Keempat 'ra' maknanya 'raisul ummah'. Santri adalah golongan masyarakat yang istiqomah menutup aurot(Falah, 2018).

\subsubsection{Madrasah Diniyah}

Madrasah diniyah adalah merupakan lembaga pendidikan yang memberikan pendidikan dan pengajaran secara klasikal yang bertujuan untuk memberi tambahan pengetahuan agama islam kepada pelajarpelajar yang merasa kurang menerima pelajaran agama islam di sekolah (Anas, 2014).

\subsubsection{Pondok Pesantren}

Pesantren merupakan lembaga pendidikan islam tertua di Indonesia sebagaimana menjadi kesepakan para peneliti sejarah pendidikan di negeri yang berpendudukan muslim terbesar didunia ini. Pada mulanya pesantren didirikan oleh para penyebar islam sehingga kehadiran pesantren diyakini mengiringi dakwah islam di negeri ini, kendati bentuk sistem pendidikannya belum selengkap pesantren sekarang.

Selanjutnya, pesantren sistem pendidikan yang melakukan kegiatan sepanjang hari. Santri tinggal di asrama dalam satu kawasan bersama guru, kiai dan senior mereka. Oleh karena itu, hubungan yang terjalin antara santri-guru-kiai dalam proses pendidikan berjalan intensif, tidak sekedar hubungan formal ustadz - santri di dalam kelas. Dengan demikian kegiatan pendidikan berlangsung sepanjang hari, dari pagi hingga malam hari (Soebahar, 2013).

\subsubsection{Metode Waterfall}

Model SDLC air terjun (waterfall) sering juga disebut model sekuensial linier (sequensial linear) atau alur hidup klasik (classic life cycle). Model air terjun menyediakan pendekatan alur hidup perangkat lunak secara sekuensial atau terurut dimulai dari analisis, desain, pengodean, dan pengujian. Berikut adalah gambar model air terjun: 


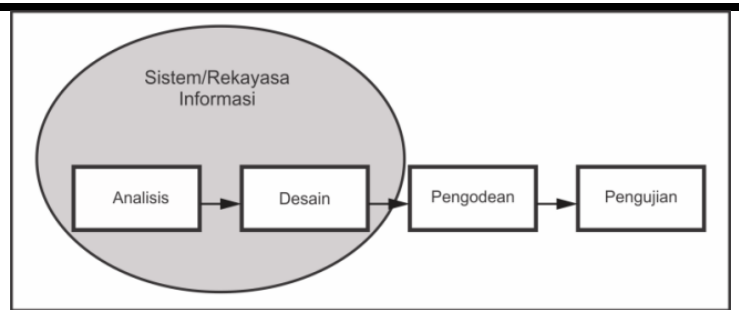

Gambar 1. Ilustrasi Model Waterfall

\subsubsection{Software Pendukung \\ a. PHP Versi 5.6.24 \\ b. Editor Text: Sublime Text 3 \\ c. Web Server: Xampp versi 3.2.2 \\ d. Database server : MySQL \\ e. Pengelola Database : phpMyAdmin \\ f. Pemodelan interface : BalsamiqMockup \\ g. Windows 10 Pro \\ h. Processor Intel ${ }^{\circledR}$ Core ${ }^{\mathrm{TM}} \mathrm{i} 5-4310 \mathrm{M}$ CPU $2.70 \mathrm{GHz}$ \\ i. $\mathrm{RAM}$ 8.00GB.}

\subsubsection{Tinjauan Objek}

Nama Instansi : Pondok Pesantren Tarbiyatul Khoirot

Alamat Instansi : Jl. Menoreh Tengah VII No. 18 Sampangan, Gajah Mungkur, Sampangan 50236

\section{METODE PENELITIAN}

\subsection{Metode Pengumpulan Data}

Metode pengumpulan data yang digunakan dalam penelitian ini adalah sebagai berikut :

a. Observasi (Pengamatan)

Dalam metode ini penulis mengadakan penelitian dengan menganalisis sistem yang berjalan, dengan cara mengadakan pengamatan langsung atau observasi lapangan melalui pengamatan langsung di saat ujian seleksi berlangsung pada Pondok Pesantren Tarbiyatul Khoirot dan mencari data seperti soal yang akan diujikan dan data lainnya yang diperlukan dalam penulisan laporan penelitian

\section{b. Wawancara (Interview)}

Wawancara adalah metode untuk mendapatkan data dengan cara mewawancarai secara lisan dan sistematis terhadap orang yang bersangkutan. Untuk mendapatkan informasi yang lebih jelas, penulis melakukan wawancara (tanya jawab) dengan beberapa pengurus dan asatidz mengenai profil deskripsi secara singkat serta alur ketika melakukan ujian seleksi tersebut hingga hasil akhir yaitu penentukan kelas Madrasah Diniyah.

c. Studi Pustaka

Selain melakukan observasi dan wawancara, penulis juga melakukan pengumpulan data dengan cara studi pustaka, dalam hal ini penulis berusaha melengkapi data-data yang diperoleh dengan cara membaca buku-buku atau literatur-literatur yang ada pada Pondok Pesantren Tarbiyatul Khoirot. Penulis juga melakukan studi pustaka melalui sumbersumber yang berhubungan dengan judul yang diajukan untuk membantu penganalisian dan sebagai acuan yang dilakukan penulis.

\section{HASIL DAN PEMBAHASAN \\ 4.1 Use Case Diagram}

Use case mendeskripsikan sebuah interaksi antara satu atau lebih aktor dengan sistem informasi yang akan dibuat. Secara kasar, use case digunakan untuk mengetahui fungsi apa saja yang ada di dalam sebuah sistem informasi dan siapa saja yang berhak menggunakan fungsi-fungsi itu (S. Rosa, 2016). Seperti yang ditunjukkan pada gambar 2 dan gambar 3.

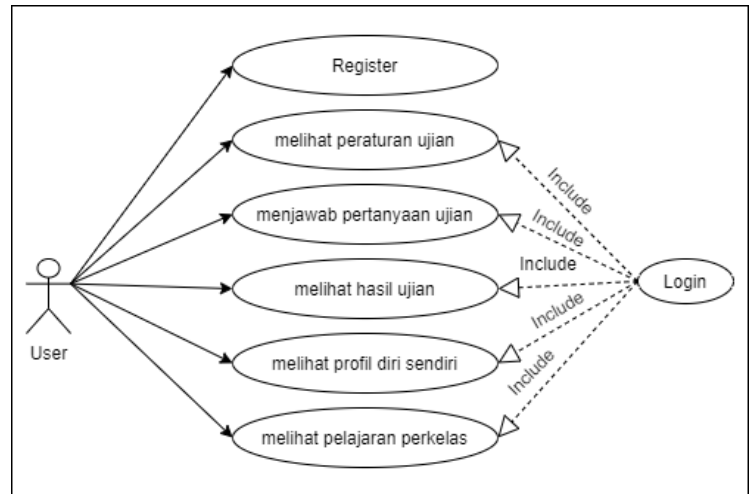

Gambar 2. Use Case User

Gambar 2 merupakan alur bagaimana proses sistem informasi penentuan kelas ini berjalan ketika user menggunakannya. Sebelum user masuk di halaman utama, user akan diarahkan untuk membuat akun terlebih dahulu pada halaman register. Sesudah mempunyai akun user dapat melakukan login dengan memasukkan username dan password. Setelah berhasil masuk, pada halaman utama terdapat peraturan yang harus disetujui agar dapat 
mengikuti ujian dan dapat diketahui hasilnya setelah ujian berakhir.

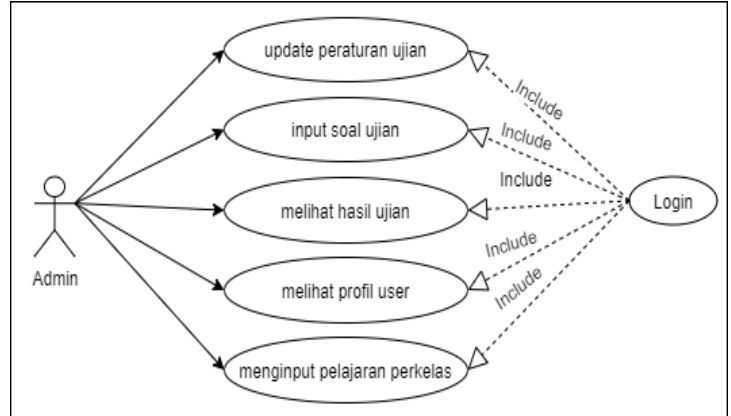

\section{Gambar 3. Use Case Admin}

Gambar 3 merupakan alur bagaimana berjalannya proses admin menggunakan sistem informasi penentuan kelas ini. Pertama admin harus melakukan login dengan memasukkan username dan password dengan benar. Setelah dapat masuk ke halaman utama, admin dapat memberikan peraturan kepada user sebelum mengikuti ujian, dapat menambah mengedit menghapus soal, dapat mengetahui data diri user dan hasil ujian user.

\subsection{Hasil}

\subsubsection{Halaman Login}

Halaman login ini ditujukan kepada admin, yang mana admin harus memasukkan username dan password agar dapat masuk ke halaman utama.

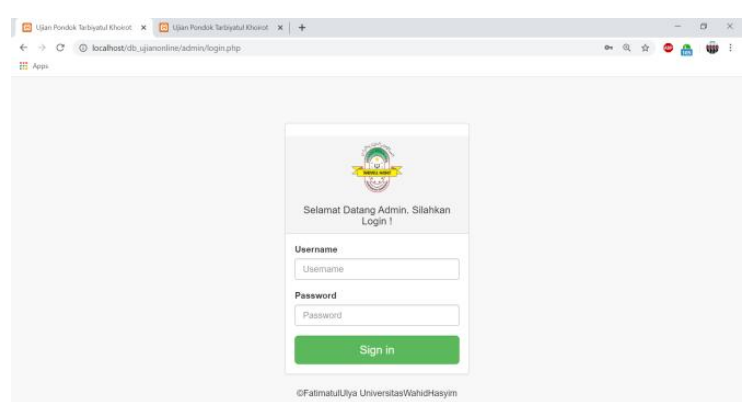

\section{Gambar 4. Halaman Login}

Pada gambar 4 merupakan halaman login yang mana admin tidak perlu registrasi untuk masuk ke halaman utama.

\subsubsection{Halaman Dashboard}

Halaman dashboard admin ini merupakan halaman utama pada admin.

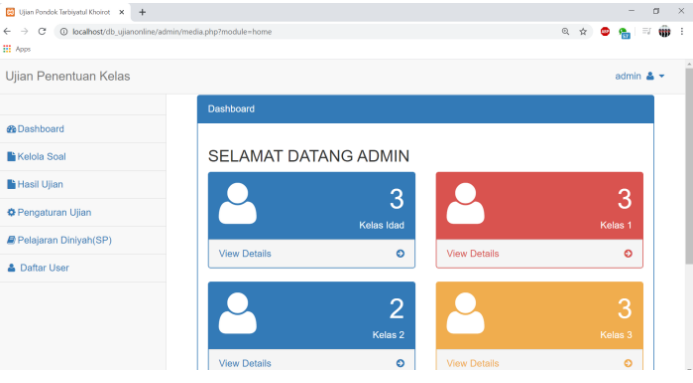

Gambar 5. Halaman Utama Admin

Pada gambar 5 merupakan tampilan halaman utama yang menampilkan notifikasi santri yang sudah registrasi, jumlah soal, dan notifikasi dari hasil masing-masing kelas.

\subsubsection{Halaman Kelola Soal}

Halaman kelola soal ini adalah halaman pembuatan soal ujian penentuan kelas.

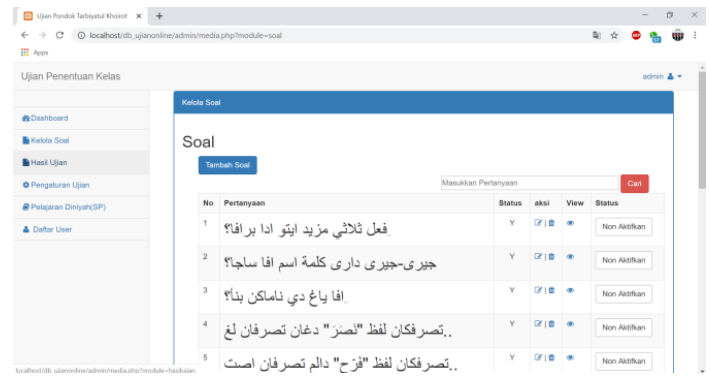

Gambar 6. Halaman Kelola Soal

Pada gambar 6 merupakan tampilan halaman kelola soal ini admin dapat mengelola soal mengenai perubahan soal, dengan mengedit soal, menambah, menghapus, melihat soal. Di halaman ini juga terdapat link untuk mencari soal.

\subsubsection{Halaman Hasil Ujian}

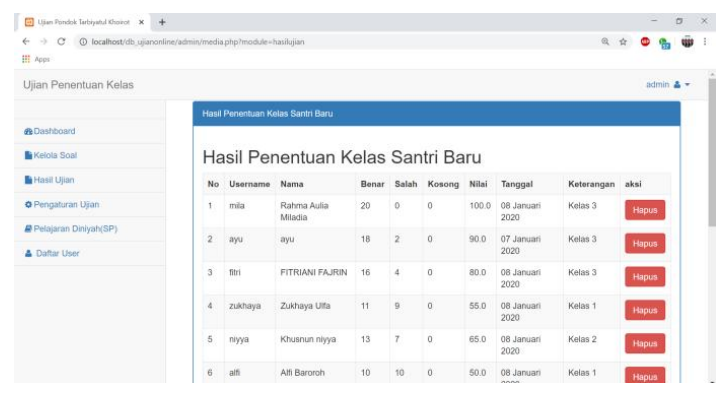

Gambar 7. Halaman Hasil Ujian 
Pada gambar 7 merupakan halaman hasil ujian ini. Admin dapat mengetahui semua hasil user dari jumlah soal yang berhasil dijawab, jumlah soal yang tidak dijawab, nilai yang diperoleh dan kelas yang didapat.

\subsubsection{Halaman Pengaturan Ujian}

Halaman pengaturan ujian ini bertujuan untuk memberi informasi untuk user sebelum melakukan ujian.

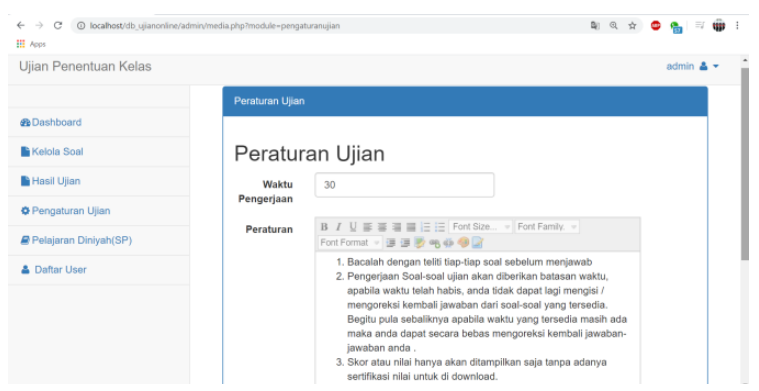

\section{Gambar 8. Halaman Pengaturan Ujian}

Pada gambar 8 merupakan halaman ujian ini admin dapat memberi aturan atau arahan kepada user mengenai hal-hal yang bersangkutan dengan ujian yang berisi form pemberitahuan batasan waktu mengerjakan dan form peraturan sebelum mengerjakan ujian.

\subsubsection{Halaman Pelajaran Diniyah}

Pada halaman pelajaran diniyah ini admin dapat memperbarui pelajaran yang akan di dapat pada masing-masing kelas.

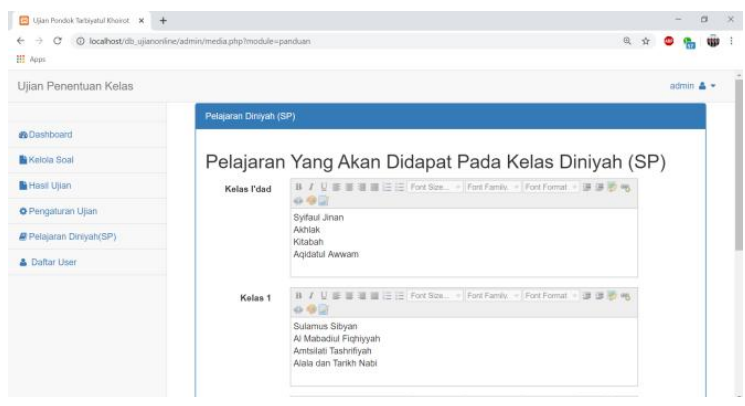

\section{Gambar 9. Halaman Pelajaran Diniyah}

Pada gambar 9 merupakan halaman pelajaran diniyah yang terdapat form yang berisi untuk menambah atau merubah pelajaran masing-masing kelas Diniyah.

\subsubsection{Halaman Daftar User}

Pada halaman daftar user ini menampilkan data user yang telah berhasil membuat akun.

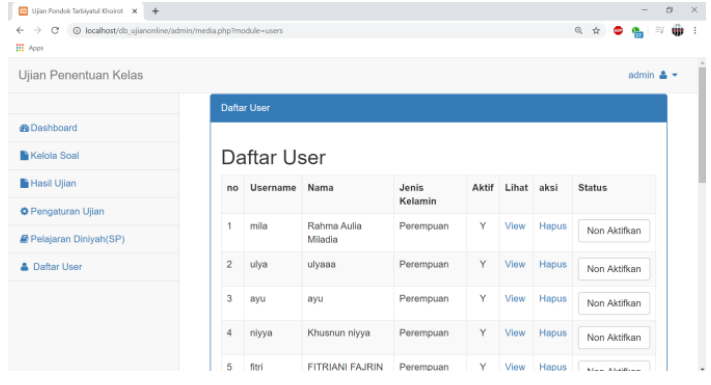

\section{Gambar 10. Halaman Daftar User}

Pada gambar 10 merupakan daftar user, admin hanya dapat melihat dan menghapus profil user dari daftar user yang sudah melakukan registrasi.

\subsubsection{Halaman Register}

Halaman register adalah halaman untuk membuat akun user sebelum melakukan login.

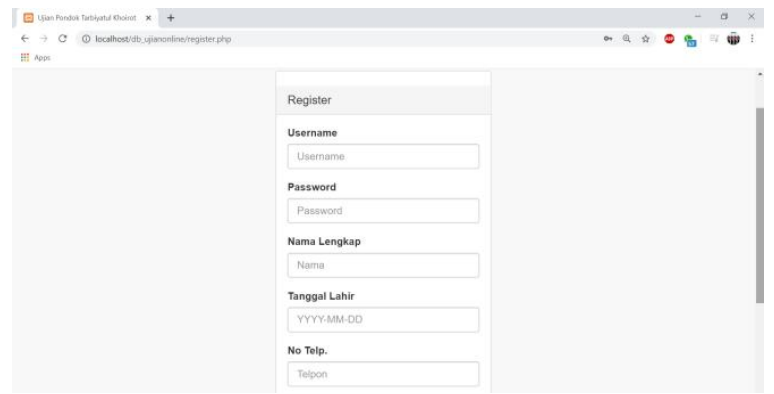

\section{Gambar 11. Halaman Register}

Pada gambar 11 merupakan halaman registrasi yang harus diisi semua formnya agar dapat mendaftar akun. Username yang telah terdaftar tidak dapat didaftarkan lagi.

\subsubsection{Halaman Login}

Pada halaman login user harus mengisi username dan password sesuai data yang pada saat registrasi. 


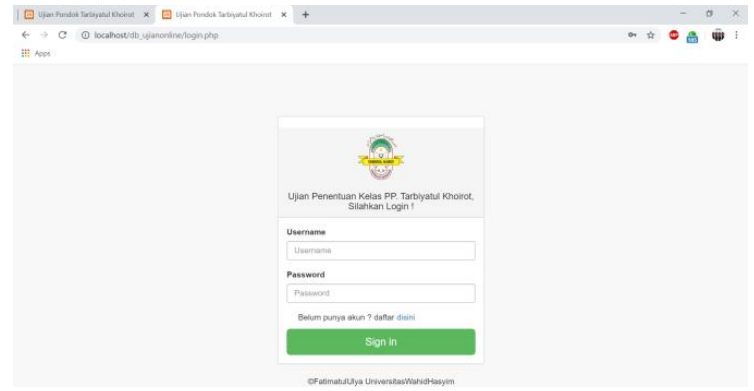

Gambar 12. Halaman Login

Gambar 12 merupakan halaman login pada user agar dapat masuk mengikuti ujian. Apabila belum memiliki akun dapat membuatnya terlebih dahulu pada tulisan disini yang berwarna biru.

\subsubsection{Halaman Dashboard}

Halaman dashboard adalah halaman utama pada user yang berisi peraturan.

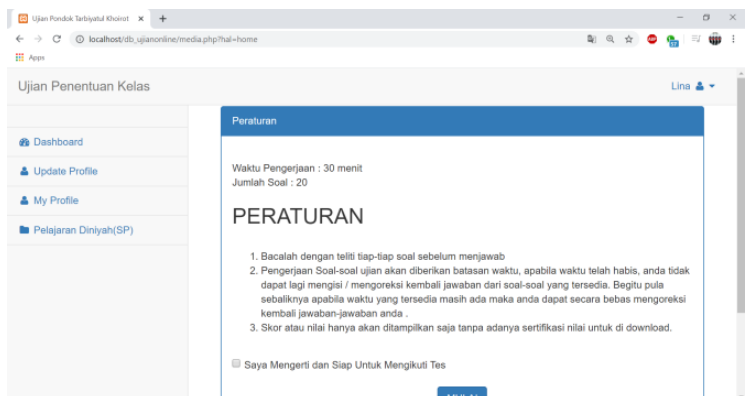

Gambar 13. Halaman Dashboard

Pada gambar 13 merupakan tampilan halaman utama yang menampilkan peraturan sebelum melakukan ujian, yang mana harus disetujui agar dapat berlanjut ke halaman soal.

\subsubsection{Halaman Soal}

Pada halaman soal menampilkan pertanyaan-pertanyaan berupa pilihan ganda dan menggunakan Bahasa pegon atau abjad arab yang dimodifikasi untuk menuliskan bahasa jawa.

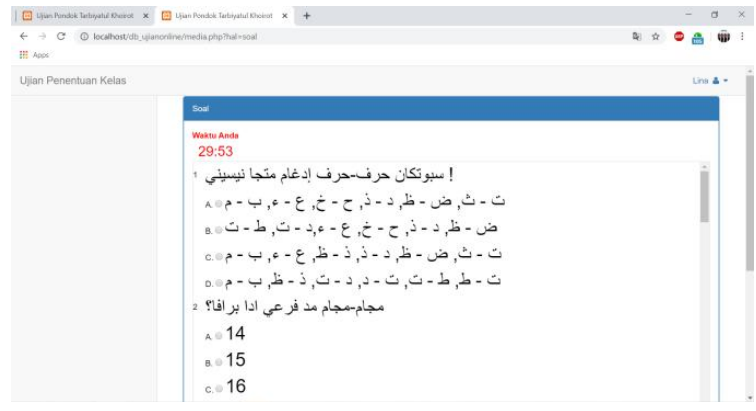

\section{Gambar 14. Halaman Soal}

Pada gambar 14 merupakan soal-soal yang diujikan dan cara mengerjakannya dengan memilih salah satu opsi dari opsi A, opsi B, opsi C, opsi D dengan cara di klik.

\subsubsection{Halaman Update Profile}

Pada halaman update profile ini user diminta untuk melengkapi data profil yang belum lengkap.

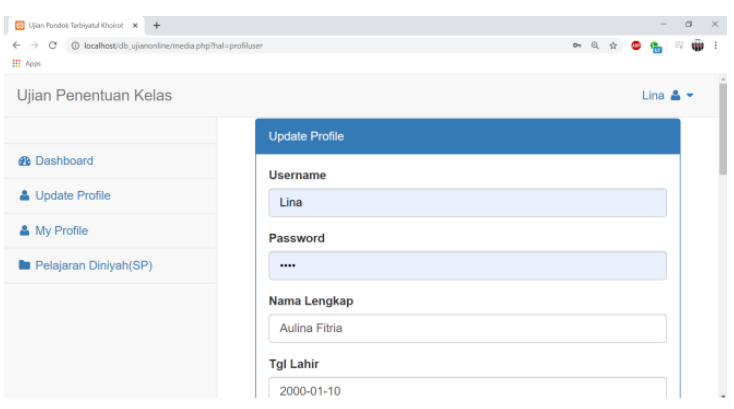

Gambar 15. Halaman Update Profile

Gambar 15 merupakan halaman update profile yang menampilkan form seperti saat registrasi. Halaman ini merupakan untuk memperbarui hal-hal jika ada perbaruan pada saat registrasi.

\subsubsection{Halaman My Profile}

Halaman my profile ini merupakan hasil dari update profile.

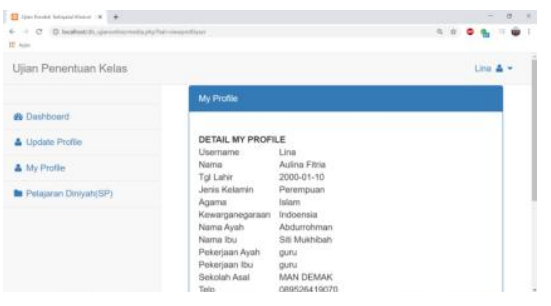

Gambar 16. Halaman My Profile 
Gambar 16 merupakan hasil dari inputan saat registrasi dan perbaruan pada halaman update profile. Pada halaman ini user hanya dapat melihat profilnya sendiri.

\subsubsection{Halaman Pelajaran Diniyah (SP)}

Halaman pelajaran diniyah ini merupakan kumpulan mata pelajaran di kelas madrasah diniyah yang bertujuan untuk memberikan informasi agar santri dapat mengetahui serta mempersiapan pelajaran atau kitab apa yang akan dipelajari dan digunakan.

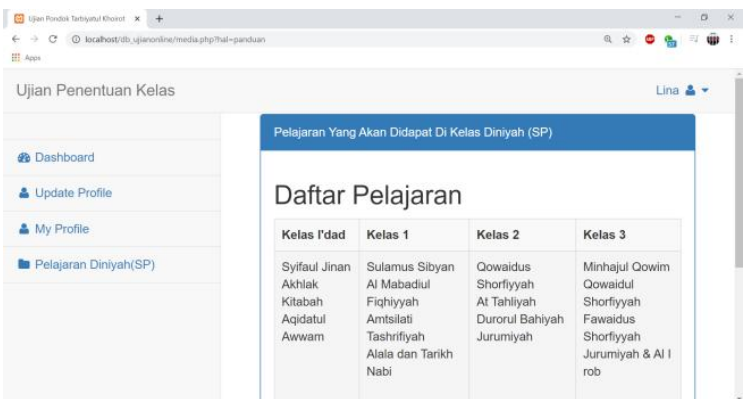

Gambar 17. Halaman Pelajaran Diniyah (SP)

Gambar 17 merupakan halaman pelajaran diniyah yang menampilkan pelajaran yang akan di dapat pada masing-masing kelas, yaitu pada kelas I'dad, kelas 1, kelas 2, dan kelas 3.

\section{KESIMPULAN DAN SARAN}

\subsection{Kesimpulan}

Berdasarkan hasil dari analisis, implementasi, dan pengujian pada sistem yang telah penulis lakukan, dapat ditarik kesimpulan bahwa sistem informasi penentuan kelas santri baru berbasis web studi kasus pada "Pondok Pesantren Tarbiyatul Khoirot" telah berhasil dibuat. Metode pengembangan sistem yang digunakan yaitu metode waterfall dan pertanyaan-pertanyaan yang digunakan pada sistem ini sesuai dengan soal pada Pondok Pesantren Tarbiyatul Khoirot yang dapat memberikan hasil dengan tepat.

\subsection{Saran}

Adapun saran yang hendak penulis sampaikan terkait sistem informasi penentu kelas bagi santri baru berbasis web pada Pondok Pesantren Tarbiyatul Khoirot yaitu :

1. Sistem informasi penentuan kelas ini masih terbilang terbatas dan kurang mendetail.
Oleh karena itu, perlu pengembangan lagi terutama dalam segi soal yang hanya berupa pilihan ganda dan dapat ditambahkan fitur print out sesuai kebutuhan.

2. Sistem informasi ini hanya terdapat ujian untuk menentukan kelas dan dapat dikembangkan untuk ujian harian atau ujian kenaikan kelas menyesuaikan dengan kebutuhan pada Pondok Pesantren Tarbiyatul Khoirot.

\section{DAFTAR PUSTAKA}

Anas, Muhammad., 2014, Tulisanku, Pustaka Education, Makassar.

Falah, Saiful., 2018, Motisantri; Inspirasi dari Negeri Santri, PT Elex Media Komputindo, Jakarta.

Julianti M.R. dan Silalahi P., 2015, Perancangan Aplikasi Ujian Online Berbasis Web Studi Kasus di STMIK Bina Srana Global, Jurnal Sisfotek Global, Vol. 5 No. 2.

Pamungkas, P.D.A., Harjunadi W., Henri S., 2015, Aplikasi Soal Ujian Seleksi Peserta Pelatihan Kejuruan Operator Komputer Berbasis Multimedia Untuk Mendukung Konsep "Paperless Office" Di PPKD Jakarta Timur, Bina Insani ICT journal Vol.2 No.1, STMIK Bina Insani, Bekasi Barat.

S, Rosa A. dan M. Shalahuddin., 2016, Rekayasa Perangkat Lunak (Terstruktur dan Berorientasi Objek), Informatika Bandung, Bandung.

Soebahar, Abd. Halim., 2013, Modernisasi Pesantren Studi Transformasi Kepemimpinan Kiai Dan Sistem Pendidikan Pesantren, LKiS Yogyakarta, Yogyakarta.

Sudaryati S., 2016. Pengembangan Online Test System Untuk Siswa Sekolah Menengah Atas, Konferensi Nasional Penelitian Matematika dan Pembelajarannya (KNPMP I), Universitas Muhammadiyah Surakarta, 686-694. 